\title{
Mitochondrial DNA diversity in anadromous rainbow smelt, Osmerus mordax Mitchill: a genetic assessment of the member-vagrant hypothesis
}

\author{
Louis Bernatchez and Sylvain Martin
}

\begin{abstract}
We analyzed mitochondrial DNA genetic variance in anadromous smelt to test whether the ecological processes inferred by the member-vagrant hypothesis to explain spatial patterns of abundance may also have evolutionary consequences for the process of population divergence. Restriction enzyme analysis was performed on 568 adult smelt from 16 sites within the estuary and the Gulf of St. Lawrence (Canada). Hierarchical analysis of heterogeneity in the frequency of 140 mitochondrial DNA genotypes and clustering analysis revealed the existence of four distinct populations among which gene flow has been restricted. This population structure appeared to be organized by the number of suitable habitats for retention of early life-history stages and their probability of diffusion among populations. This suggests that ecological processes inferred by the member-vagrant hypothesis may be a primary factor controlling population genetic diversity in anadromous smelt. Biogeographic events may also have played a major role in shaping smelt population genetic diversity. Our results emphasize the importance of considering the interplay between the life-history characteristics of a species, its genetic diversity, and environmental constraints in a historical perspective to better understand its evolutionary ecology.
\end{abstract}

\begin{abstract}
Résumé : Nous avons analysé la variance génétique de l'ADN mitochondrial chez l'Éperlan arc-en-ciel anadrome afin de vérifier si les processus écologiques expliquant les patrons de distribution spatiale selon l'hypothèse de «member-vagrant » pouvaient également avoir des conséquences évolutives sur le processus de divergence des populations. Un total de 568 éperlans adultes provenant de 16 sites de l'estuaire et du golfe du Saint-Laurent (Canada) ont été analysés par enzymes de restriction. Les analyses de groupement et hiérarchique de l'hétérogénéité de la fréquence de 140 haplotypes mitochondriaux ont mis en évidence quatre populations distinctes entre lesquelles le flux génique est restreint. Cette structure populationnelle semble correspondre au nombre d'habitats favorables à la rétention des jeunes stades et à leur probabilité de diffusion entre populations. Ces résultats suggèrent que les processus écologiques sous-jacents à l'hypothèse de « member-vagrant » ont un effet déterminant sur la diversité génétique de l'Éperlan. De plus, des facteurs biogéographiques ont probablement joué un rôle important sur la détermination de cette diversité. Dans l'ensemble, cette étude illustre l'importance de considérer dans une perspective historique les interactions entre les caractéristiques du cycle vital d'une espèce, sa diversité génétique et les contraintes environnementales afin de mieux en comprendre l'écologie évolutive.
\end{abstract}

\section{Introduction}

Explaining the extent, causes, and consequences of biotic distribution in space is fundamental to our understanding of how species evolve to cope in particular environments. In the past decade, the member-vagrant hypothesis has provided a major theoretical framework for studying the role of ecological processes in determining spatial patterns of abundance in aquatic species, particularly for marine ecosystems (Iles and Sinclair 1982; Sinclair 1988; Sinclair and Iles 1988, 1989). This hypothesis proposes that the population structure of a species evolves primarily as a consequence of selective forces that maximize the probability of encounter among sexually mature

Received April 19, 1995. Accepted August 4, 1995.

J12877

L. Bernatchez ${ }^{1}$ and S. Martin. Département de biologie, Pavillon Vachon, Université Laval, Sainte-Foy, QC

G1K 7P4, Canada.

1 Author to whom all correspondence should be addresssed. e-mail: louis.bernatchez@bio.ulaval.ca individuals and the survival of early life-history stages. One prediction of this hypothesis is that the number of populations composing a given species will primarily be determined by the number of environmental settings (geographic, physical, oceanographic) to which (i) spawning adults are adapted to home and (ii) early life history is behaviorly adapted to permit retention. This implies that in situations where the distribution of larvae is different from the distribution of spawning sites, population structure should reflect the number of retention zones rather than that of spawning sites (Sinclair 1988).

The member-vagrant hypothesis has been supported by evidence of a correlation between the number of early lifehistory retention zones and the number of distinct fish groups determined almost exclusively by geographic discreteness, phenotypic variation in life-history traits, or other biological characteristics that may reflect locally varying environmental factors (reviewed in Sinclair 1988). In contrast, little attention has been given to the impact that such processes operating at the ecological scale could have at an evolutionary scale, namely by restricting gene flow among groups associated with different retention zones, thus enhancing potential for local adaptation and ultimately promoting reproductive isolation. 
Fig. 1. Collection sites and frequency distribution of mtDNA haplotypes among anadromous smelt from the estuary and Gulf of St. Lawrence. Frequencies are given as percentages for pooled sampling sites of each of the four populations (I to IV) defined in Fig. 3: all mtDNA group B genotypes (solid), subcluster A11 (open), single haplotype 1 (hatched), and all other mtDNA group A genotypes (vertical lines).

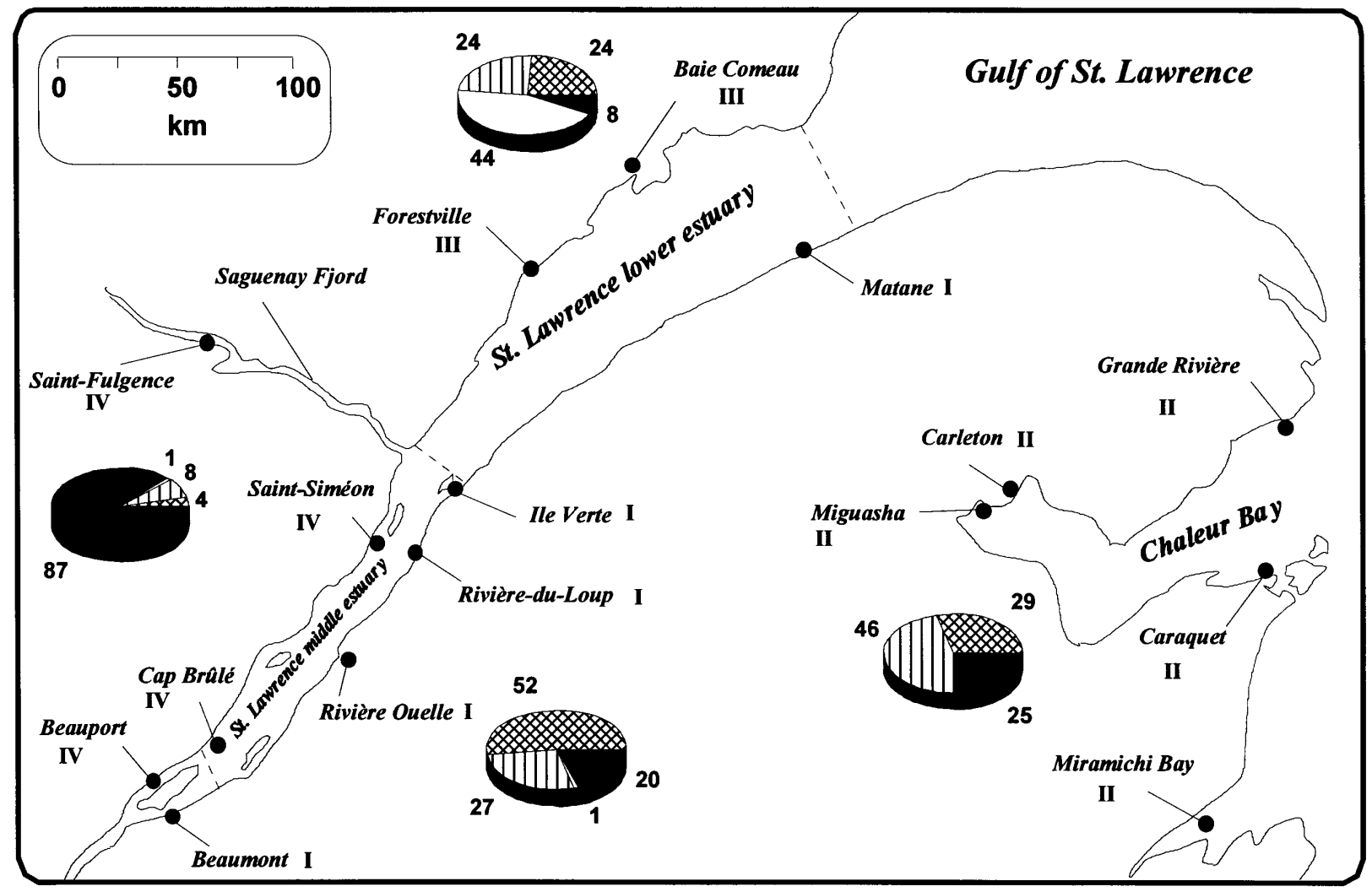

The hypothesis that these ecological processes may have evolutionary consequences for population divergence would be supported by a correlation between the number of groups associated with potential retention zones and significant partitioning of genetic variance among them. Available genetic data do not clearly support this prediction. On one hand, the genetic population structure of species found at both extremes of the "continuum of population richness" (Fig. 5.12 of Sinclair 1988), such as American eel, Anguilla rostrata (Avise et al. 1986), and Atlantic menhaden, Brevoortia tyrannus (Bowen and Avise 1990), which are population poor, or Atlantic salmon, Salmo salar (reviewed in Davidson et al. 1989), American shad, Alosa sapidissima (Bentzen et al. 1989), and striped bass, Morone saxatilis (Chapman 1990; Wirgin et al. 1993), which are population rich, conforms to the species' number of retention zones. In contrast, null or very low genetic subdivision has generally been reported in species characterized by an intermediate number of retention zones, such as Atlantic cod, Gadus morhua (Carr and Marshall 1991), haddock, Melanogrammus aeglefinus (Zwanenburg et al. 1992), Atlantic herring, Clupea harengus harengus (Kornfield and Bogdanowicz 1987), capelin, Mallotus villosus (Dodson et al. 1991), and American plaice, Hippoglossoides platessoides (Stott et al. 1992). While these results may truly reflect genetic homogeneity among groups associated with distinct retention zones, it is also possible that in some cases, the sample sizes or specific levels of polymorphism for the genetic markers used were inappropriate to obtain statistically significant results (Ovenden 1990; Ferguson 1994).

Rainbow smelt, Osmerus mordax, is native to watersheds tributary to the western Atlantic Ocean from New Jersey to the Labrador coast (Scott and Crossman 1973). Anadromous populations of this species exhibit a similar life cycle: adult smelt ascend streams and rivers in early spring and spawn in fresh water. Hatching occurs 1-2 weeks later and larvae from different spawning sites are usually transported within short periods into estuarine or marine coastal waters where they are retained in estuaries (e.g., Ouellet and Dodson 1985; Laprise and Dodson 1989a, 1989b), fjords, or coastal embayments until metamorphosis. In Quebec waters, previous studies of variation in biological characters and parasite occurrence supported the proposition that the number of phenotypically distinct smelt groups reflects the number of larval retention zones rather than the number of spawning sites (Fréchet et al. 1983a, $1983 b$ ). These studies revealed the existence of three phenotypic smelt groups: the south shore of the St. Lawrence middle estuary, Chaleur Bay, and the Saguenay Fjord (Fig. 1). In addition, the existence of a fourth group along the north shore of the lower estuary was suggested.

In recent years, the analysis of mitochondrial DNA (mtDNA) variation has proven most useful in assessing the genetic structure of smelt populations (Baby et al. 1991; Taylor and Bentzen 1993a, 1993b; Taylor and Dodson 1994). Namely, a restriction analysis of mtDNA variation supported 
Table 1. Location, collection date, sample size, number of mitochondrial genotypes, and nucleon diversity $(h)$ estimates for 16 anadromous smelt samples from the estuary and Gulf of St. Lawrence.

\begin{tabular}{lccccc}
\hline Sampling site & Region & Date & $n$ & $\begin{array}{c}\text { No. of } \\
\text { genotypes }\end{array}$ & $h$ \\
\hline Beaumont & I & April 1990 & 36 & 13 & 0.73 \\
Rivière-Ouelle & I & May 1990 & 36 & 14 & 0.75 \\
Rivière-du-Loup & I & Nov. 1992 & 36 & 14 & 0.69 \\
Île Verte & I & Dec. 1992 & 36 & 12 & 0.71 \\
Matane & I & Nov. 1992 & 36 & 13 & 0.73 \\
Grande-Rivière & II & Oct. 1993 & 36 & 19 & 0.83 \\
Rivière Nouvelle & II & May 1990 & 36 & 24 & 0.95 \\
Miguasha & II & Jan. 1994 & 36 & 24 & 0.91 \\
Caraquet & II & Oct. 1993 & 36 & 17 & 0.87 \\
Miramichi River & II & May 1991 & 36 & 23 & 0.95 \\
Forestville & III & Jan. 1993 & 36 & 15 & 0.83 \\
Baie Comeau & III & Jan. 1993 & 35 & 11 & 0.78 \\
Beauport* & IV & May 1993 & 36 & - & - \\
Cap-Brûlé & IV & Oct. 1992 & 30 & 12 & 0.74 \\
Saint-Siméon & IV & Nov. 1992 & 33 & 13 & 0.87 \\
Saint-Fulgence & IV & March 1993 & 35 & 11 & 0.71 \\
\hline
\end{tabular}

Note: Region refers to the geographic population designation as defined in Figs. 1 and 3.

*The number of genotypes and nucleon diversity were not quantified for Beauport as individuals of that site were successfully characterized for only a subset of restriction enzymes allowing us to classify them to major phylogenetic groups A and B (Fig. 2).

the hypothesis that smelt from the south shore of the St. Lawrence middle estuary composed a single population, genetically distinct from smelt of Chaleur Bay (Baby et al. 1991). The limited number of samples, however, precluded the partitioning of genetic variance among the four regional smelt groups proposed by Fréchet et al. (1983a, 1983b).

In this study, we performed a more comprehensive restriction fragment length polymorphism (RFLP) mtDNA analysis of anadromous smelt to test the hypothesis that ecological processes inferred by the member-vagrant hypothesis to explain patterns of geographic and phenotypic discreteness in aquatic species also translate into significant genetic subdivision, and therefore, may have evolutionary consequences for the process of population divergence.

\section{Material and methods}

\section{Sample collection}

An average of 36 reproductive females were obtained between 1990 and 1994 from 16 sampling sites covering the distribution of the four smelt groups described by Fréchet et al. $(1983 a, 1983 b)$ as well as the Miramichi River, New Brunswick (Fig. 1, Table 1). Fish were captured either on spawning grounds or in nearby wintering areas, with the exception of one sample (Saint-Siméon) that was obtained from a fall commercial fishery. The four samples obtained in 1990-1991 were those previously analyzed by Baby et al. (1991). mtDNA was extracted from fresh or frozen ovaries according to Chapman and Powers (1984) as modified by Bernatchez et al. (1988). Restriction enzymes, electrophoresis, and digests procedures were the same as in Baby et al. (1991). This methodology insured complete compatibility with data obtained in that study. Six hexameric (ApaI, BglI, BstEII, DraI, EcoRV, and PstI), four multihexameric (AvaI,
BanI, BanII, and HincII), and two multipentameric (AvaII, NciI) restriction enzymes were used.

\section{Data analysis}

Composite mtDNA genotypes were defined by distinct combinations of polymorphic restriction sites observed across all restriction enzymes. Relationships among genotypes were assessed by using the restriction site presence-absence matrix to generate phylogenetic trees according to Wagner parsimony criteria using the MIX program of the PHYLIP 3.5c computer package (Felsenstein 1993). A majorityrule consensus tree was constructed using the CONSENSE program and confidence statements on branches were estimated by running the MIX program on 100 bootstrapped matrices of the restriction site data generated by the SEQBOOT program.

Relationships among all samples were estimated by computing Nei's (1978) genetic distance $(D)$, treating mtDNA genotypes as alleles of a single locus. The resulting pairwise matrix of genetic distance estimates was used to construct a phenogram relating samples using the unweighted pair-group method of arithmetic averages (UPGMA, Sneath and Sokal 1973). The significance of population clustering was assessed by a hierarchical analysis of heterogeneity in the frequencies of mtDNA genotypes (Sokal and Rohlf 1981), using $\chi^{2}$ randomization tests (Roff and Bentzen 1989) with 1000 permutations performed by the MONTE program of the REAP software package (McElroy et al. 1992). The heterogeneity test was first performed on the overall population set, and then among population clusters, beginning with the most divergent. This $\chi^{2}$ decomposition procedure was performed until no significant heterogeneity was detected.

The geographic differentiation of mtDNA variation was further assessed using the analysis of molecular variance model (AMOVA) of Excoffier et al. (1992). This procedure calculated standard variance components, and an array of haplotypic correlation measures, referred to as Phi statistics for different levels of population. The significance of the observed values for those parameters was tested using a random permutation procedure available in the AMOVA computer package. This avoids the parametric assumptions of normality and independence that are rarely met by genetic distance measures. By this approach, we computed the variance components resulting from molecular differences at three hierarchical levels: among groups, among populations within groups, and within populations. The definition of groups was based on the number of significant clusters depicted in the population phenogram. We also computed pairwise fixation indices $\left(F_{\text {st }}\right)$ among significant groups by omitting the molecular information of divergence among mtDNA genotypes and simply considering those as multiple alleles of a single locus (Excoffier et al. 1992). This also provided an estimate of the effective number of females exchanged per generation among groups according to the approximation $N_{\mathrm{e}} m_{\mathrm{f}}=\left(1 / F_{\mathrm{st}}-1\right) / 2$. Although the veracity of the absolute $N_{\mathrm{e}} m_{\mathrm{f}}$ estimates depends on several assumptions that may not be met in the present situation $(m \ll 1$, population in equilibrium with respect to genetic drift and migration, selective neutrality, island model of population structure), they nevertheless provide a comparative basis for estimating differential gene flow among populations.

\section{Results}

\section{mtDNA diversity and phylogenetic differentiation}

The 12 restriction enzymes used allowed the recognition of 197 different restriction sites, including 68 synplesiomorphies, 84 autapomorphies, and 45 synapomorphies. These resolved a total of 140 mtDNA genotypes among 568 smelt that were screened, of which 58 were previously reported in Baby et al. (1991). A complete description of composite haplotypes and 
Fig. 2. Unrooted majority-rule consensus network showing relationships among $140 \mathrm{mtDNA}$ genotypes identified in anadromous smelt from the estuary and the Gulf of St. Lawrence. Bootstrap confidence statements higher than the $50 \%$ majority-rule criterion are given along branches. Numbers at the tips of branches identify genotypes with their total abundance given in parentheses. The scale of 0.001 substitution/site corresponds to one restriction site difference.

\section{group B}
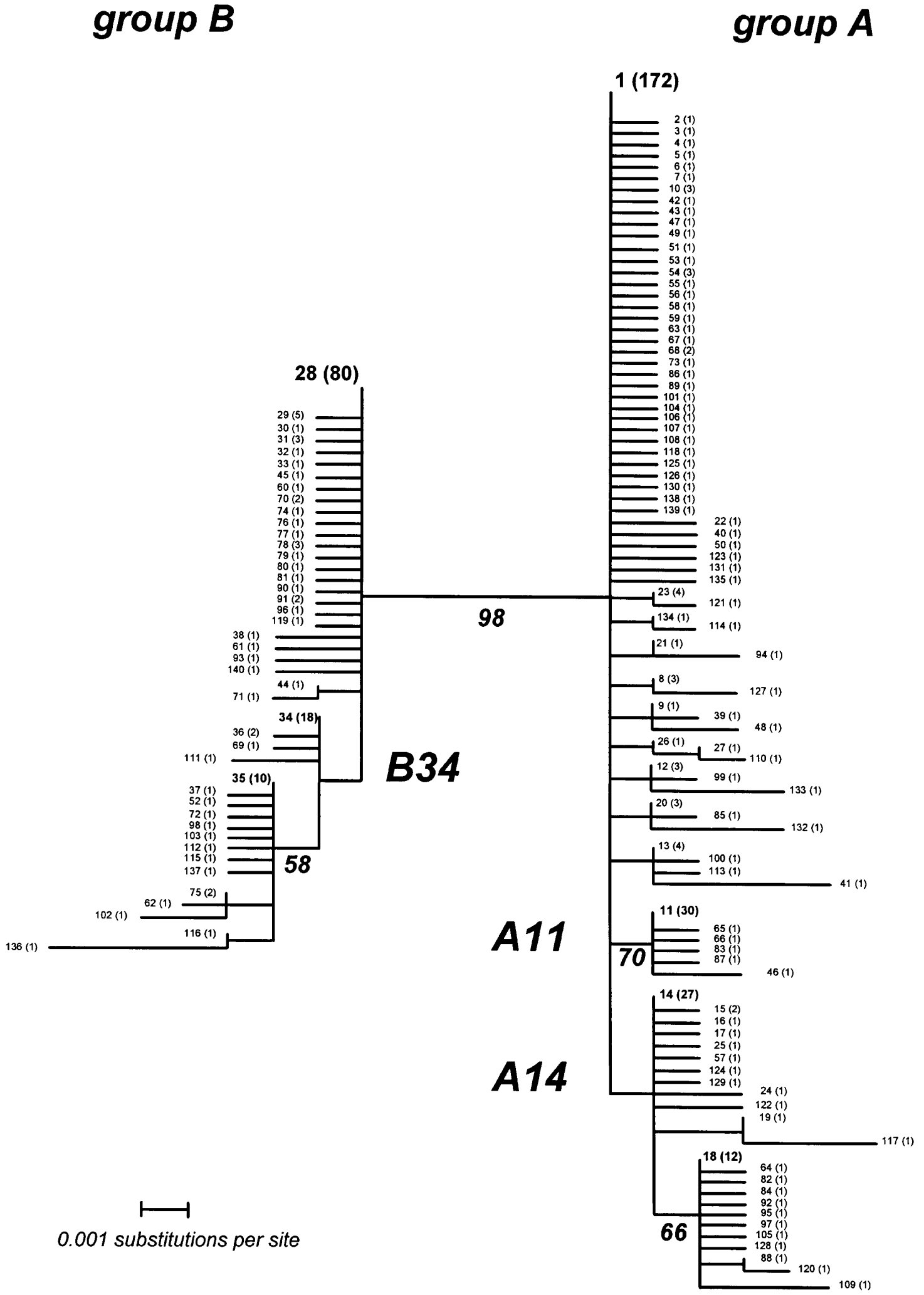
Fig. 3. UPGMA population tree clustering anadromous smelt samples into four population groups (I to IV) according to the matrix of Nei's genetic distance. Levels of significance $(P)$ in the frequency distribution of mtDNA genotypes among clusters are given along branches. The clustering of the Beauport sample was only based on the relative frequency of mtDNA groups A and $\mathrm{B}$ as not all restriction enzymes were resolved for that site.

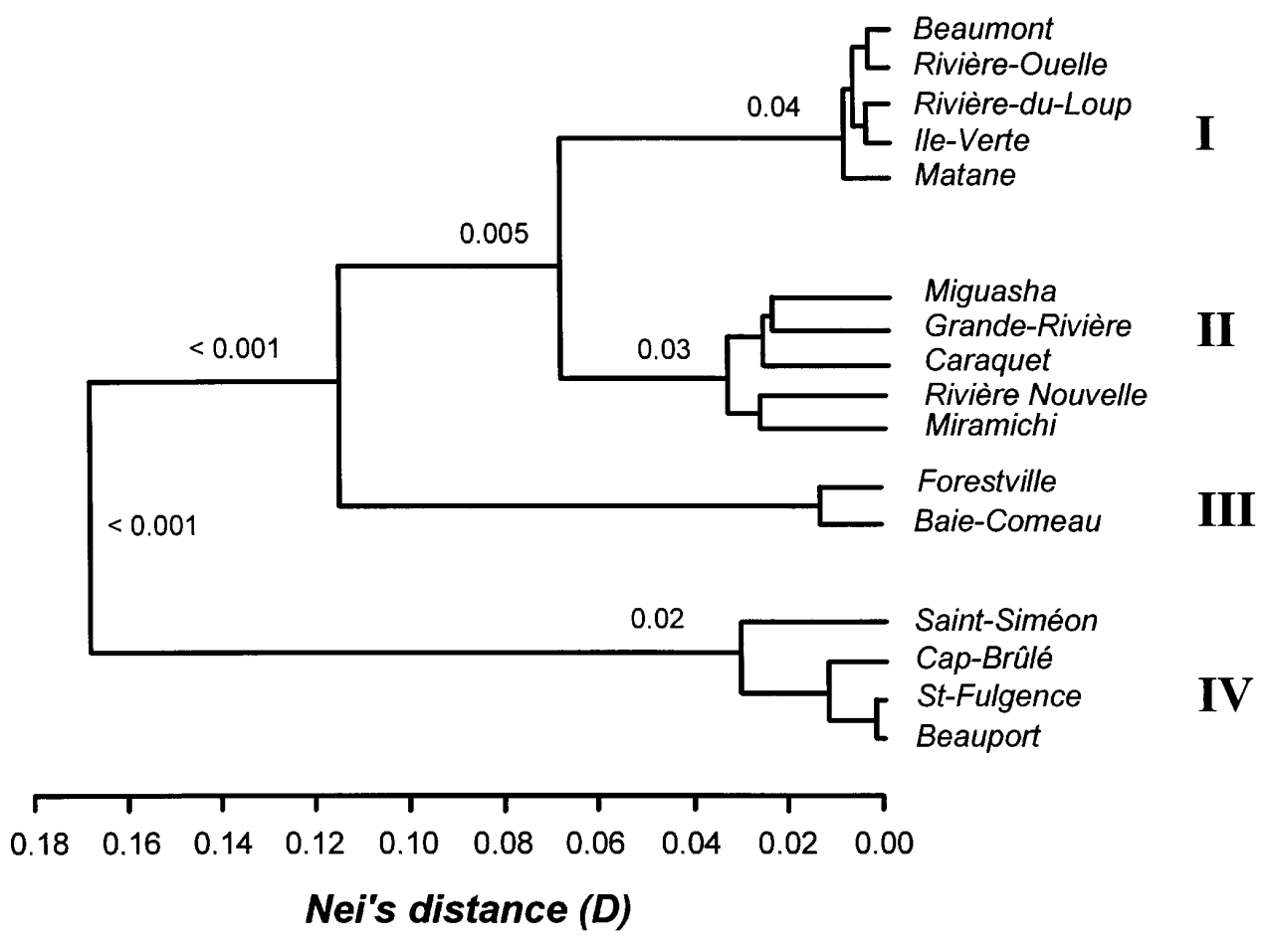

Table 2. The hierarchical analysis of molecular variance of mitochondrial DNA genotypes among anadromous smelt of the estuary and Gulf of St. Lawrence.

\begin{tabular}{lrrcc}
\hline & & $\%$ total & Phi & \\
Variance component & df & variance & statistic & $P$ \\
\hline Among groups & 3 & 22.38 & $\mathrm{CT}=0.224$ & 0.001 \\
Among samples within group & 11 & 0.00 & $\mathrm{SC}=0.000$ & 0.672 \\
Within samples & 507 & 77.62 & $\mathrm{ST}=0.221$ & 0.001 \\
\hline
\end{tabular}

their frequency distribution is provided elsewhere (Bernatchez 1995; Bernatchez et al. 1995).

As illustrated by the topology of the unrooted majority-rule consensus tree (Fig. 2), all mtDNA genotypes clustered into two monophyletic mtDNA groups (A and B) that were supported at a $98 \%$ bootstrapping level. These two groups were differentiated by six apomorphies generated by the restriction enzymes ApaI, AvaII ( $n=2)$, BanII, HincII, and NciI, and the average pairwise sequence divergence among genotypes from both groups was $0.83 \%$. Within each of them, the overall topology was a starlike phylogeny in which a central genotype (genotype 1 in group A, genotype 28 in group B) dominated in abundance and was surrounded by a majority of rarer genotypes generally derived by one or two mutational steps. Additional subclustering, however, was also observed. In phylogenetic group A, subclusters A11 and A14 were composed of 6 and 23 genotypes, respectively, sharing a unique apomorphy in each case. Subcluster A11 was supported at a $70 \%$ bootstrapping level whereas A14 was not significant un- der the $50 \%$ majority-rule criterion. Within group B, subcluster B34 comprised 17 genotypes sharing a unique apomorphy. However, only the branch grouping genotypes 35-137 obtained significant support under the $50 \%$ majority-rule consensus criterion.

\section{Population diversity and relationships}

The population UPGMA phenogram generated from Nei's genetic distance matrix clustered the 16 samples into significant clusters exhibiting a clear geographic pattern of distribution (Figs. 1, 3). Group I included all samples from the south shore of the St. Lawrence estuary, group II those from Chaleur Bay and Miramichi River, group III those from the north shore of the St. Lawrence lower estuary, and group IV those from the north shore of the St. Lawrence middle estuary and the Saguenay Fjord. Genetic distances among samples within each cluster were low and significant differences in haplotype frequencies were observed in only three comparisons. Within group II, the Nouvelle and Miramichi River samples differed slightly from the others, as did the Matane sample within group I and the Saint-Siméon sample within group IV.

The four groups were characterized by a distinctive mtDNA feature (Fig. 1). The smelt assemblage from the north shore of the St. Lawrence middle estuary and the Saguenay Fjord (group IV) was largely dominated (87\%) by genotypes belonging to phylogenetic group $\mathrm{B}$, which was much less abundant among other groups. Smelt samples from the north shore of the St. Lawrence lower estuary (group III) were characterized by a high frequency of genotypes (44\%) belonging 
Table 3. Pairwise comparisons of Phi-CT (below main diagonal) and $F_{\text {st }}$ (above) coefficients among four genetically distinct anadromous smelt populations from the estuary and Gulf of St. Lawrence.

\begin{tabular}{lllrr}
\hline Population & I & II & III & IV \\
\hline I. St. Lawrence middle-lower estuary (south shore) & 0.000 & $0.032(15.0)$ & $0.132(3.3)$ & $0.178(2.3)$ \\
II. Chaleur Bay - Miramichi River & 0.008 & 0.000 & $0.075(6.2)$ & $0.100(4.5)$ \\
III. St. Lawrence lower estuary (north shore) & 0.087 & 0.089 & 0.000 & $0.181(2.3)$ \\
IV. St. Lawrence middle estuary (north shore) - Saguenay Fjord & 0.407 & 0.323 & 0.551 & 0.030 \\
\hline
\end{tabular}

Note: Indirect estimates of long-term migratory exchange of females per generation $\left(N_{\mathrm{e}} m_{\mathrm{f}}\right)$ among populations are given in parentheses. The main diagonal gives the $F_{\text {st }}$ coefficients estimated among sites within each population.

to subcluster A11, which was observed in only three individuals elsewhere. The St. Lawrence south shore and Chaleur Bay groups (I and II) were less distinctive; the former showed a higher proportion of the single genotype 1 whereas the latter was characterized by a high occurrence of rare genotypes belonging to phylogenetic group A. The high occurrence of rare genotypes in Chaleur Bay also translated into nucleon diversity $(h)$ values that were higher $(t$ value $=7.07, \mathrm{df}=8, P<$ $0.0001)$ than those observed for group I (Table 1).

\section{Components of genetic variance}

The analysis of molecular variance components also supported the patterns of high homogeneity within and significant genetic heterogeneity among the four smelt groups (Table 2). Thus, the nested analysis of population structure revealed that $22.38 \%$ of the total mtDNA genotypic diversity was explained by the variance among the four groups, whereas variance among sites within groups was null. Most of the overall diversity $(77.62 \%)$ was attributable to variability within populations. The permutation procedure showed that the partitioning of variance among groups (Phi-CT) and within samples (PhiST) was highly significant.

Pairwise comparisons of molecular variance (Phi-CT estimates) among groups were highly variable. The lowest differentiation was observed between group I (St. Lawrence south shore) and group II (Chaleur Bay) for which molecular variance was less than $1 \%$ (Table 3 ). This suggested relatively high effective migration rates between the two regional populations, as reflected by the $N_{\mathrm{e}} m_{\mathrm{f}}$ value of 15.0. Intermediate values were observed between group III (north shore of the St. Lawrence lower estuary) and the latter two populations. Clearly, group IV was the most distinctive, with $32-55 \%$ of the total genetic diversity explained by intergroup variance when compared with any of the other regional populations, including that associated with the south shore of the St. Lawrence estuary, for which samples were generally obtained less than $20 \mathrm{~km}$ away.

\section{Discussion}

\section{mtDNA diversity in anadromous smelt}

To reveal significant population structure, a genetic technique must show levels of variation commensurate with the questions being addressed. The overall mtDNA genotypic diversity in anadromous smelt observed in this study $(h=0.858)$ was above that generally observed in other anadromous species (compiled in Billington and Hebert 1991). As reported in previous studies of mtDNA variation in smelt, haplotypes grouped into two phylogenetic groups (A and B), within which several individual genotypes or groups of genotypes were found at moderate to high frequencies, thus representing potentially informative markers to statistically address variation in genotypic frequencies and genetic diversity.

The high level of haplotype diversity coupled with the statistical analysis of genetic variance partitioning revealed a highly significant population structure in anadromous smelt. The 16 samples analyzed clustered into four groups showing a sharp geographic distribution. The genetic distinctiveness of these groups was supported by genetic distance values and significant differences in mtDNA haplotype distribution, as well as significant molecular variance estimates in pairwise comparisons among all groups. Within-group estimates of these parameters were generally null and not statistically significant, which suggests that extensive gene flow occurs among sites within each group. These results suggest that the anadromous smelt covered in this study comprise four genetically distinct populations among which gene flow has been restricted to variable extents. These populations were associated with distinct regions: the south shore of the St. Lawrence estuary (I), Chaleur Bay - Miramichi River (II), the north shore of the St. Lawrence lower estuary (III), and the north shore of the St. Lawrence middle estuary - Saguenay Fjord (IV). Mild but significant heterogeneity in the frequency distribution of genotypes was found within some of these populations, suggesting incomplete panmixia. Namely, smelt from the Matane sample, which represented the only collection site on the south shore of the lower estuary, differed significantly from the other smelt within population I, as did the Miramichi River smelt within group II. These observations may be interpreted from two perspectives. From a population genetic perspective, this suggests that even though effective migration between these sites and others from the same region has been much more important than among regions, it may have remained sufficiently small to allow significant divergence in mtDNA gene frequencies. From an ecological perspective, this suggests that short-term fluctuations in abundance at these sites could depend more on local recruitment and mortality than immigration and emigration. The Saint-Siméon sample also differed slightly within group IV. In this case, however, the distinction was most likely due to the fact that this sample was obtained from a fall commercial fishery and represented a mixture of smelt from the north- and south-shore populations of the middle estuary (Bernatchez et al. 1995).

\section{Congruence in mtDNA and phenotypic population structure}

Genetic subdivisions observed in this study reinforced earlier interpretations of smelt population structure based on preliminary genetic analyses and variation in biological characters. 
For example, our data confirmed the hypothesis that smelt from the south shore of the St. Lawrence estuary comprised a population distinct from that in Chaleur Bay (Baby et al. 1991). The four populations identified by patterns of mtDNA diversity were also highly congruent with the classification of anadromous smelt into four regional groups (Chaleur Bay, south shore of St. Lawrence estuary, north shore of St. Lawrence lower estuary, and Saguenay Fjord) as proposed by Fréchet et al. $(1983 a, 1983 b)$. Our study also indicated that the Saguenay Fjord group identified by these authors is not limited to the Saguenay River but extends eastward to the north shore of the St. Lawrence middle estuary. Therefore, the analysis of mtDNA variation confirmed that phenotypic variation in anadromous smelt was not solely due to the effect of variable expression of a single gene pool in the face of locally varying environmental factors but also demonstrated genetic divergence.

\section{Smelt population structure and the member-vagrant hypothesis}

Significant genetic subdivision was observed among all smelt populations, which suggested that gene flow has been insufficient to counteract their divergence through genetic drift and (or) selection. Our results, therefore, imply that smelt populations have the potential to develop local adaptations and follow distinct evolutionary trajectories. Consequently, the demonstration that the population genetic structure observed in smelt is primarily determined by the number of distinct environmental settings permitting retention of early life-history stages would provide support for the hypothesis that ecological processes inferred by the member-vagrant hypothesis (Sinclair 1988) may have evolutionary consequences for the process of population divergence. Two conditions must be met to make such an inference. First, it must be shown that the number of genetically distinct populations is more dependent on the number of suitable habitats permitting early life-history stage retention and survival than the number of spawning sites. Secondly, evidence must be provided that the extent of gene flow among populations is primarily affected by levels of dispersal of young rather than older life-history stages.

Our results provided some evidence that ecological factors affecting the distribution of young life-history stages may be important in shaping smelt genetic population structure. Thus, they clearly indicated that population richness was not primarily determined by the number of spawning sites, as illustrated by the general lack of genetic subdivision among smelt obtained from different sites within the four populations identified. There is also support for an association between genetic subdivisions and distinct retention zones for at least two of these populations. Studies of larval smelt provided sound evidence that the St. Lawrence middle estuary represents a suitable habitat within which drifting larvae from spawning tributaries located on the estuary of the south shore are retained by active vertical displacements in combination with the circulation system (Ouellet and Dodson 1985; Laprise and Dodson 1989a, 1989b). There is also evidence that Chaleur Bay constitutes a distinct oceanographic setting (Legendre and Watt 1970; El-Sabh and Ingram 1992) that could potentially retain smelt larvae associated with that system, although the larval ecology of that population has not been investigated.

Evidence that the extent of gene flow is primarily affected by levels of dispersal of young rather than older life-history stages can be inferred by comparing the species ontogenic constraints to movements within the studied area. Regardless of life-history stages, gene flow among smelt populations must primarily be governed by ecological and (or) genetic factors as there are no physical barriers (such as land or insufficient water depth) that can effectively separate them. There are no apparent physiological or environmental barriers that could limit juvenile and adult smelt dispersal among the different regions covered in this study. Thus, suitable salinity and temperature conditions for the older life-history stages of smelt can be found all over the estuary and the Gulf of St. Lawrence (Scott and Scott 1988; Nellbring 1989). Furthermore, tagging studies have shown that smelt are capable of migrating long distances in a relatively short period. For instance, Magnin and Beaulieu (1965) reported that the recovery distance for smelt tagged in the St. Lawrence estuary averaged $150 \mathrm{~km}$, while several individuals were recaptured more than $300 \mathrm{~km}$ away. These authors also reported displacement rates up to $42 \mathrm{~km} /$ day, and no clear pattern in the frequency of recaptures upstream or downstream of tagging sites. This suggests that geographic distance is not an important limiting factor for smelt movements among populations. This conclusion is supported by the general lack of correlation observed between geographic and genetic distances in the present study. Altogether, these observations suggest that the dispersal capability of older smelt life-history stages is not a major constraint to gene flow among the populations surveyed.

In contrast, there are several indications that the potential for larval dispersal among populations may be highly controlled by environmental constraints. Ecological studies have shown that anadromous smelt larvae are typically associated with low salinity, being generally rare where it exceeds 20 g/kg (Able 1978; Laprise and Dodson 1989a; de Lafontaine 1990). This suggests that zones of high salinity may hamper survival of smelt larvae that diffuse from retention zones. Such conditions are typically found in the Laurentian channel of the lower estuary, which may limit dispersal between populations associated with both shores. Similarly, high salinity also characterizes coastal waters on the south shore of the estuary downstream of Matane (Koutitonsky and Bugden 1991), which could limit dispersal between the St. Lawrence estuary and Chaleur Bay populations.

Other oceanographic features may also restrict transport of vagrant larvae among populations. For example, the mouth of the Saguenay River (Fig. 1) is characterized by the presence of two distinct water masses, rapid depth changes, and tidally induced upwelling that creates fronts (steep gradients of physical conditions) that could prevent transport and diffusion between smelt populations of the middle and lower estuary (Ingram and El-Sabh 1990). The effect of environmental constraints on gene flow mediated by larval dispersion is also suggested by comparing levels of population differentiation in relationships with water circulation patterns. The general current pattern in the St. Lawrence lower estuary is characterized by an intense south-shore buoyant jet, and a less intense coastal current that flows seaward and parallel to the north shore. The latter current flows southward across the mouth of the estuary to join the south-shore jet and a strong coastal current, the Gaspé current, which flows along the coast of the Gaspé peninsula, towards Chaleur Bay. This circulation 
pattern apparently offers little possibility for larval diffusion between populations located on the two shores of the lower estuary. In contrast, it could potentially favour larval drift along the south shore of the Gaspé peninsula down to Chaleur Bay. This may partly explain why the estimated number of female migrants per generation between the St. Lawrence south shore and Chaleur Bay populations $\left(N_{\mathrm{e}} m_{\mathrm{f}}=15\right)$ was five times higher than that observed between the south- and northshore populations in the lower estuary $\left(N_{\mathrm{e}} m_{\mathrm{f}}=3.3\right)$ despite the fact that much shorter distances separate these latter two (e.g., $75 \mathrm{~km}$ between Matane and Baie-Comeau versus $300 \mathrm{~km}$ between Matane and Grande-Rivière).

Altogether, these observations strongly suggest that the number of genetically distinct populations found in anadromous smelt is more dependent on the number of suitable habitats for retention of early life-history stages than the number of spawning sites. They also suggest that gene flow may be more constrained by the probability of transport and diffusion of young life-history stages among populations than the potential for movements of older stages. Thus, ecological processes inferred by the member-vagrant hypothesis to explain the distribution of young life-history stages may be a primary factor controlling population genetic diversity in anadromous smelt. Additional factors, however, must be invoked to explain the strong genetic subdivision observed among some populations.

\section{Historical events and population divergence}

The most salient feature of this study was the demonstration of pronounced genetic differentiation between smelt samples collected on the north shore of the St. Lawrence middle estuary and the Saguenay Fjord (population IV) and all other populations. Thus, estimates of genetic subdivision involving pairwise comparisons of population IV were always more significant than for comparisons among other populations (averaged $F_{\text {st }}=0.153$ versus 0.061 ), regardless of the geographic distance involved. This is best reflected by the genetic subdivision between populations from the south (I) and north (IV) shores of the middle estuary, which was approximately six times more pronounced than that between the south shore and Chaleur Bay (II) populations despite the much closer geographic proximity of the samples from the north and south shores (approximately $20 \mathrm{~km}$ ) compared with the distance separating the middle estuary and Chaleur Bay (approximately $700 \mathrm{~km}$ ). As reflected by estimates of the number of effective female migrants per generation, this suggests that historical and (or) contemporary gene flow has been more restricted between populations found on both shores of the middle estuary than between the south-shore and Chaleur Bay populations. This genetic structure cannot be solely explained by the effect of ecological processes inferred by the member-vagrant hypothesis. Thus, the middle estuary is generally recognized as one oceanographic setting characterized by a well-mixed zone in the upstream section and partially stratified water in the downstream part (El Sabh 1988) within which smelt larvae are retained by active and passive processes (Laprise and Dodson $1989 a, 1989 b)$. Furthermore, strong transversal currents related to the general cyclonic circulation pattern of the middle estuary (Ouellet and Trump 1979) promote larval transport across the estuary. Consequently, preliminary analyses of the spatial distribution of young life-history stages suggests important mixing of larvae and fry of both populations
(Bernatchez et al. 1995, D. Pigeon, Département de biologie, Université Laval, unpublished data). In such a situation, the member-vagrant hypothesis would predict the existence of a single population in that system.

This suggests that the genetic differentiation between north- and south-shore smelt populations may primarily be due to reproductive isolation imposed by genetic rather than ecological constraints. Unlike the distinction among other populations that is primarily based on differential frequency distribution of haplotypes belonging to mtDNA phylogenetic group $\mathrm{A}$, the uniqueness of population IV is due to the predominance of phylogenetic group B haplotypes. The phylogenetic basis of this differentiation is further illustrated by comparing $F_{\text {st }}$ and Phi-CT estimates, the latter taking into account both the differences in haplotype frequency distribution and their nucleotide divergence. Thus, values obtained for both estimates were comparable in pairwise comparisons not involving population IV (mean $F_{\mathrm{st}}=0.080$, mean Phi-CT $=$ 0.061), which suggests a weak phylogenetic component to their differentiation. In contrast, Phi-CT estimates were about three times higher than $F_{\text {st }}$ values in comparisons including population IV (mean $F_{\text {st }}=0.153$, mean Phi-CT $=0.440$ ), which reflects a strong phylogenetic component associated with the differential distribution of mtDNA groups A and B. Therefore, the genetic differentiation of population IV from all others may more likely be explained by historical rather than contemporary factors. On the basis of the net sequence divergence estimate between mtDNA groups A and B (0.7\%) and the range of mutation rates reported for the fish mitochondrial genome (Meyer 1994), it is very unlikely that they were derived from a common ancestor in postglacial times. An alternative explanation may be that mtDNA groups A and B are associated with two smelt assemblages that evolved in separate glacial refugia and subsequently recolonized the contemporary range of the species. This scenario is partly suggested by the differential pattern of distribution of the two groups in previous studies of mtDNA variation in smelt (Taylor and Bentzen 1993a), although a more complete phylogeographic study of the species is required to test this hypothesis. If true, this phylogenetic hypothesis implies that the St. Lawrence estuary represents a zone of secondary contact of two glacial races of smelt that have developed some biological barriers to gene flow. The possibility for the development of reproductive isolation mechanisms between intraspecific groups derived from allopatric divergence in glacial times has previously been documented for other fishes, namely the whitefish (Coregonus sp.) species complex (Bernatchez and Dodson 1990; Bernatchez et al. 1996).

In summary, the pattern of mtDNA diversity observed in anadromous smelt supports the hypothesis that the species' genetic population structure is primarily determined by the number of environmental settings controlling the distribution and dispersal of early life-history stages. This implies that ecological processes inferred by the member-vagrant hypothesis (Sinclair 1988) to explain geographic and phenotypic discreteness in aquatic organisms may also translate into genetic divergence, and therefore may have evolutionary consequences for the process of population divergence. Our results also indicated that biogeographic events probably have played a major role in shaping the population genetic diversity of anadromous smelt. Our study therefore illustrates the importance 
of considering the interplay between the life-history characteristics of a species, its genetic diversity, and environmental constraints in a historical perspective to better understand its evolutionary ecology.

\section{Acknowledgments}

This study was financially supported by grants from the ministère de l'Environnement et de la Faune (MEF, Quebec), the Department of Fisheries and Oceans (Canada), the Natural Sciences and Engineering Research Council of Canada and Fonds pour la formation de chercheurs et l'aide à la recherche (Quebec) to L.B. We gratefully acknowledge Serge Tremblay, Guy Trencia, Guy Verreault, and Yvan Vigneault for their helpful comments and suggestions. We also thank André Bernier for laboratory assistance and Rémi Tardif, Mathieu Bélanger, Gilles Mercier, Jean-Luc Brisebois, Roger Picard, and Raymond Bossé (MEF) for their participation in sample collection.

\section{References}

Able, K.W. 1978. Ichthyoplankton of the St. Lawrence estuary: composition, distribution, and abundance. J. Fish. Res. Board Can. 35: $1518-1531$.

Avise, J.C., Helfman, G.S., Saunders, S., Stanton, N.C., and Hales, L. 1986. Mitochondrial DNA differentiation in North Atlantic eels: population genetic consequences of an unusual life history pattern. Proc. Natl. Acad. Sci. U.S.A. 83: 4350-4354.

Baby, M.-C., Bernatchez, L., and Dodson, J.J. 1991. Genetic structure and relationships among anadromous and landlocked populations of rainbow smelt (Osmerus mordax, Mitchill) as revealed by mitchondrial DNA restriction analysis. J. Fish Biol. 39(Suppl. A): 61-68.

Bentzen, P., Brown, G.C., and Leggett, W.C. 1989. Mitochondrial DNA polymorphism, population structure and life history variation in American shad (Alosa sapidissima). Can. J. Fish. Aquat. Sci. 46: 1446-1454.

Bernatchez, L. 1995. Détermination du degré de différenciation génétique entre échantillons d'Éperlan arc-en-ciel (Osmerus mordax Mitchill) provenant de la pêcherie hivernale de Miguasha et de sites éloignés de la Baie-des-Chaleurs. Ministère de l'Environnement et de la Faune, Direction régionale Gaspésie - Iles-de-laMadeleine, Service de l'aménagement et de l'exploitation de la faune, New-Richmond, and Institut national de la recherche scientifique (INRS-Eau).

Bernatchez, L., and Dodson, J.J. 1990. Allopatric origin of sympatric populations of lake whitefish (Coregonus clupeaformis) revealed by mitochondrial DNA restriction analysis. Evolution, 44: 1263-1271.

Bernatchez, L., Savard, L., Dodson, J.J., and Pallotta, D. 1988. Mitochondrial DNA sequence heterogeneity among James-Hudson Bay anadromous coregonines. Finn. Fish. Res. 9: 17-26.

Bernatchez, L., Martin, S., Bernier, A., Tremblay, S., Trencia, G., Verreault, G., and Vigneault, Y. 1995. Conséquences de la structure génétique de l'Éperlan arc-en-ciel (Osmerus mordax) pour la réhabilitation de l'espèce dans l'estuaire du Saint-Laurent. Rapport Saint-Laurent Vision 2000.

Bernatchez, L., Vuorinen, J.A., Bodaly, R.A., and Dodson, J.J. 1996. Genetic evidence for reproductive isolation and multiple origins of sympatric trophic ecotypes of whitefish (Coregonus). Evolution, 50: 624-635.

Billington, N., and Hebert, P.D.N. 1991. Mitochondrial DNA diversity in fishes and its implications for introductions. Can. J. Fish. Aquat. Sci. 48(Suppl. 1): 80-94.
Bowen, B.W., and Avise, J.C. 1990. Genetic structure of Atlantic and Gulf of Mexico populations of sea bass, menhaden, and sturgeon: influence of zoogeographic factors and life-history patterns. Mar. Biol. (Berlin), 107: 371-381.

Carr, S.M., and Marshall, H.D. 1991. Detection of intraspecific sequence variation in the mitochondrial cytochrome $b$ gene of Atlantic cod (Gadus morhua) by the polymerase chain reaction. Can. J. Fish. Aquat. Sci. 48: 48-52.

Chapman, R.W., and Powers, D.A. 1984. A technique for the rapid isolation of mitochondrial DNA from fishes. Technical report. Maryland Sea Grant Program.

Chapman, R.W. 1990. Mitochondrial DNA analysis of striped bass populations in Chesapeake Bay. Copeia, 335: 355-366.

Davidson, W.S., Birt, T.P., and Green, J.M. 1989. A review of genetic variation in Atlantic salmon, Salmo salar L., and its importance for stock identification, enhancement programs and aquaculture. J. Fish Biol. 34: 547-560.

de Lafontaine, Y. 1990. Ichthyoplankton communities in the St. Lawrence Estuary: composition and dynamics. In Oceanography of a large-scale estuarine system. Edited by M.I. El-Sabh and N. Silverberg. Springer-Verlag, New York. pp. 321-343.

Dodson, J.J., Carscadden, J.E., Bernatchez, L.L., and Colombani, F. 1991. Relationship between spawning mode and phylogeographic structure in mitochondrial DNA of North Atlantic capelin (Mallotus villosus) populations. Mar. Ecol. Prog. Ser. 76: 103-113.

El-Sabh, M.I. 1988. Physical oceanography of the St. Lawrence estuary. In Hydrodynamics of estuaries. Vol. II. Estuarine case studies. Edited by B. Kjerfve. CRC Press, Inc., Boca Raton, Fla. pp. 61-78.

El-Sabh, M.I., and Ingram, G.B. 1992. Large-scale hydrodynamic studies of Baie des Chaleurs in support of scallop research. In Proceedings of the 26th Annual Conference of the Canadian Meteorological and Oceanographical Society, Québec, Que.

Excoffier, L., Smouse, P.E., and Quattro, J.M. 1992. Analysis of molecular variance inferred from metric distances among DNA haplotypes: application to human mitochondrial DNA restriction data. Genetics, 131: 479-491.

Felsenstein, J. 1993. PHYLIP (phylogeny inference package). Version 3.5c. Department of Genetics, SK.-50, University of Washington, Seattle, Wash.

Ferguson, M. 1994. The role of molecular genetic markers in the management of cultured fishes. Rev. Fish Biol. Fish. 4: 351-373.

Fréchet, A., Dodson, J.J., and Powles, H. 1983a. Use of variation in biological characters for the classification of anadromous rainbow smelt (Osmerus mordax) groups. Can. J. Fish. Aquat. Sci. 40: $718-727$.

Fréchet, A., Dodson, J.J., and Powles, H. 1983b. Les parasites de l'Éperlan d'Amérique (Osmerus mordax) anadrome du Québec et leur utilité comme étiquettes biologiques. Can. J. Zool. 61: 621-626.

Iles, T.D., and Sinclair, M. 1982. Atlantic herring: stock discreteness and abundance. Science (Washington, D.C.), 215: 627-633.

Ingram, R.G., and El-Sabh, M.I. 1990. Fronts and mesoscale features in the St. Lawrence estuary. In Oceanography of a large-scale estuarine system. Edited by M.I. El-Sabh and N. Silverberg. Springer-Verlag, New York. pp. 71-93.

Kornfield, I., and Bogdanowicz, S.M. 1987. Differentiation of mitochondrial DNA in Atlantic herring, Clupea harengus. Fish. Bull. 85: 561-568.

Koutitonsky, V.G., and Bugden, G.L. 1991.The physical oceanography of the Gulf of St. Lawrence: a review with emphasis on the synoptic variability of the motion. In The Gulf of St. Lawrence: small ocean or big estuary? Edited by J.-C. Therriault. Can. Spec. Publ. Fish. Aquat. Sci. No. 113. pp. 57-90.

Laprise, R., and Dodson, J.J. 1989a. Ontogeny and importance of tidal vertical migrations in the retention of larval smelt Osmerus 
mordax in a well-mixed estuary. Mar. Ecol. Prog. Ser. 55: 101-111.

Laprise, R., and Dodson, J.J. 1989b. Ontogenetic changes in the longitudinal distribution of two species of larval fish in a turbid wellmixed estuary. J. Fish Biol. 35(Suppl. A): 39-47.

Legendre, L., and Watt, D. 1970. The production of primary production relative to a cyclonic gyre in Baie des Chaleurs. Mar. Biol. (Berlin), 7: 167-170.

Magnin, E., and Beaulieu, G. 1965. Quelques données sur la biologie de l'Éperlan Osmerus eperlanus mordax (Mitchill) du SaintLaurent. Nat. Can. (Que.), 92: 81-105.

McElroy, D., Moran, P.E., Bermingham, E., and Kornfield, I. 1992. REAP: an integrated environment for the manipulation and phylogenetic analysis of restriction data. J. Hered. 83: 157-158.

Meyer, A. 1994. Molecular phylogenetic studies of fish. In Genetics and evolution of aquatic organisms. Edited by A.R. Beaumont. Chapman \& Hall, London. pp. 219-248.

Nei, M. 1978. Estimation of average heterozygosity and genetic distance from a small number of individuals. Genetics, 89: 583-590.

Nellbring, S. 1989. The ecology of smelts (genus Osmerus): a literature review. Nord. J. Freshwater Res. 65: 116-145.

Ouellet, P., and Dodson, J.J. 1985. Dispersion and retention of anadromous rainbow smelt (Osmerus mordax) larvae in the middle estuary of the St. Lawrence River. Can. J. Fish. Aquat. Sci. 42: 332-341.

Ouellet, Y., and Trump, C. 1979. La circulation hydrodynamique dans la zone de mélange estuarienne du Saint-Laurent. Nat. Can. (Que.), 106: 13-26.

Ovenden, J.R. 1990. Mitochondrial DNA and marine stock assessment: a review. Aust. J. Mar. Freshwater Res. 41: 835-853.

Roff, D.A., and Bentzen, P. 1989. The statistical analysis of mitochondrial DNA polymorphisms: $\chi^{2}$ and the problem of small samples. Mol. Biol. Evol. 6: 539-545.

Scott, W.B., and Crossman, E.J. 1973. Freshwater fishes of Canada. J. Fish. Res. Board Can. Bull. No. 184.
Scott, W.B., and Scott, M.G. 1988. Atlantic fishes of Canada. Can. Bull. Fish. Aquat. Sci. No. 219.

Sinclair, M. 1988. Marine populations. An essay on population regulation and speciation. University of Washington Press, Seattle, Wash.

Sinclair, M., and Iles, T.D. 1988. Population richness of marine fish species. Aquat. Living Resour. 1: 71-83.

Sinclair, M., and Iles, T.D. 1989. Population regulation and speciation in the oceans. J. Cons. Cons. Int. Explor. Mer, 45: 165-175.

Sneath, P.H.A., and Sokal, R.R. 1973. Numerical taxonomy. Freeman Press, San Francisco.

Sokal, R.R., and Rohlf, F.J. 1981. Biometry. W.H. Freeman and Company, New York.

Stott, W., Ferguson, M.M., and Tallman, R.F. 1992. Genetic population structure of American plaice (Hippoglossoides platessoides) from the Gulf of St. Lawrence, Canada. Can. J. Fish. Aquat. Sci. 49: $2538-2545$.

Taylor, E.B., and Bentzen, P. 1993a. Evidence for multiple origins and sympatric divergence of trophic ecotypes of smelt (Osmerus) in northeastern North America. Evolution, 47: 813-832.

Taylor, E.B., and Bentzen, P. 1993b. Molecular genetic evidence for reproductive isolation between sympatric populations of smelt Osmerus in Lake Utopia, south-western New Brunswick, Canada. Mol. Ecol. 2: 345-357.

Taylor, E.B., and Dodson, J.J. 1994. A molecular analysis of relationships and biogeography within a species complex of holarctic fish (genus Osmerus). Mol. Ecol. 3: 235-248.

Wirgin, I., Maceda, L., Waldman, J.R., and Crittenden, R.N. 1993. Use of mitochondrial DNA polymorphisms to estimate the relative contributions of the Hudson River and Chesapeake Bay striped bass stock to the mixed Atlantic coastal fishery. Trans. Am. Fish. Soc. 122: 669-684.

Zwanenburg, K.C.T., Bentzen, P., and Wright, J.M. 1992. Mitochondrial DNA differentiation in western North Atlantic populations of haddock (Melanogrammus aeglefinus). Can. J. Fish. Aquat. Sci. 49: 2527-2537. 